\title{
Assessing the Land Use/Cover Dynamics and its Impact on the Low Flow of Gumara Watershed, Upper Blue Nile Basin, Ethiopia
}

Gashaw G Chakilu* and Mamaru A Moges²

${ }^{1}$ College of Agriculture, Wolaita Sodo University, Sodo 138, Ethiopia

${ }^{2}$ Faculty of Civil and Water Resources Engineering, Bahir Dar Institute of Technology, Bahir Dar University, Bahir Dar, Ethiopia

\begin{abstract}
Land cover and Climate change are very important issues in terms of global context and their responses to environmental and socio-economic drivers. The dynamic of these two factors is currently affecting the environment in unbalanced way including watershed hydrology. In this paper the impact of land use/cover change on stream flow particularly on low flow were evaluated through application of the model Soil and Water Assessment Tool (SWAT) in Gumara watershed, Upper Blue Nile basin Ethiopia. The land use/cover data were obtained from Land Sat image and processed by ERDAS IMAGINE 2010 software. Three land use land cover data; 1973, 1986, and 2013 were prepared and these data were used for base map, model calibration and change study respectively. So, as to evaluate the effect of land use/cover change on low flow of the catchment, the stream flow was simulated by changing 1973 and 2013 LULC but the climate data, which is 1973-1982, was used and it was constant. The low flow of the catchment for these two decades was extracted in simulated flows by Seven Day Sustained (SDS) low flow separation method. The model (SWAT) was calibrated by 1986-1991 climate data and 1986 land use land cover data by using 11 important model parameters selected by sensitivity analysis. The consistency of values of those calibrated parameters was also validated by 1992-1995 climates and with the same land use land cover data. Based on the result, the extreme low flow of Gumara watershed has been decreasing from $0.53 \mathrm{~m}^{3} / \mathrm{s}$ to $0.43 \mathrm{~m}^{3} / \mathrm{s}$ which showed decreasing by $0.1 \mathrm{~m}^{3} / \mathrm{s}$ that is $18.87 \%$. From the overall results of the study, it is possible to conclude that land use land cover change has been influencing the low flow or dry season flow of the catchment. This study has been designed to show how much the land use/cover has been changed and affects the low flow or dry season environmental flow of the catchment. The result has showed some indications that there has to be restoration activities on the land use cover nature of the study area.
\end{abstract}

Keywords: LULC; Low flow; SWAT; Gumara; Blue Nile; Ethiopia

\section{Introduction}

Land cover change and climate change and associated impacts on water resources are being the hot issues in recent years. This is due to the direct or indirect impacts brought by land use and climate change both have contributed to some water problems, such as water shortage, flooding, and water logging to different extent.

The response of hydrology to land use/cover change is an integrated in ecosystem, and may affect the overall healthy functions of a watershed and its ecosystems. Direct and powerful linkages exist among spatially distributed watershed properties and watershed processes [1]. Water shortages and degradation of water supplies threaten the food security and health of people in many parts of the world. This is particularly happened in developing countries that are experiencing rapid population growth and inefficient means to manage water resources [2]. Land use land cover (LULC) changes, particularly those caused by human activities-for example deforestation to clear land for agriculture, are considered to be the most important factor in global environmental change, exerting effects possibly greater than those of other global changes [3].

In Ethiopian, on the head of Blue Nile and in lake Tana basin, over the past few decades there have been a lot of activities that have modified the land use/land cover. Moreover, the hydrological dynamics has been strongly modified by intensive agricultural activities. This has a direct impact on the lake and the flow condition of Abay (upper Blue Nile) as well. Therefore, it is very important to understand the functioning of the lake catchments and their hydrological response under different historical land use and climate change scenario conditions and the water resources development of the basin requires a judicious planning for the protection of the fragile ecosystem. Thus, this study will focus on responses of low flow for the dynamics of land use/cover of Gumera watershed which is part of Lake Tana and upper Blue Nile basin.

\section{Materials and Methods}

\section{Study area description}

The Gumara River is located to the east direction of Lake Tana; it is found between latitude of $11^{\circ} 35^{\prime}$ and $11^{\circ} 55^{\prime} \mathrm{N}$ and longitude of $37^{\circ}$ $40^{\prime}$ and $38^{\circ} 10^{\prime} \mathrm{E}$. And it has a total drainage area of 127186 ha up to the gauging station (near Woreta), a head of $25 \mathrm{~km}$ before it joins the lake. The total main stream length from its origin (near mount Guna) is approximately $132.5 \mathrm{~km}$ before the river joins Lake Tana (Figure 1).

\section{General research methods}

The effect of land use/cover change on the low river flow of the study area has been simulated by using SWAT hydrological model. The simulated flow generated by the SWAT model was compared with the observed one by using Nash Sutcliff efficiency and relative volume error by the help of excel sheet. To enhance the agreement of simulated

*Corresponding author: Gashaw G Chakilu, College of Agriculture, Wolaita Sodo University, Sodo 138, Ethiopia, Tel: +251912334295; E-mail: ggismu@yahoo.com

Received February 10, 2017; Accepted March 03, 2017; Published March 10, 2017

Citation: Chakilu GG, Moges MA (2017) Assessing the Land Use/Cover Dynamics and its Impact on the Low Flow of Gumara Watershed, Upper Blue Nile Basin, Ethiopia. Hydrol Current Res 7: 268. doi: 10.4172/21577587.1000268

Copyright: @ 2017 Chakilu GG, et al. This is an open-access article distributed under the terms of the Creative Commons Attribution License, which permits unrestricted use, distribution, and reproduction in any medium, provided the original author and source are credited. 


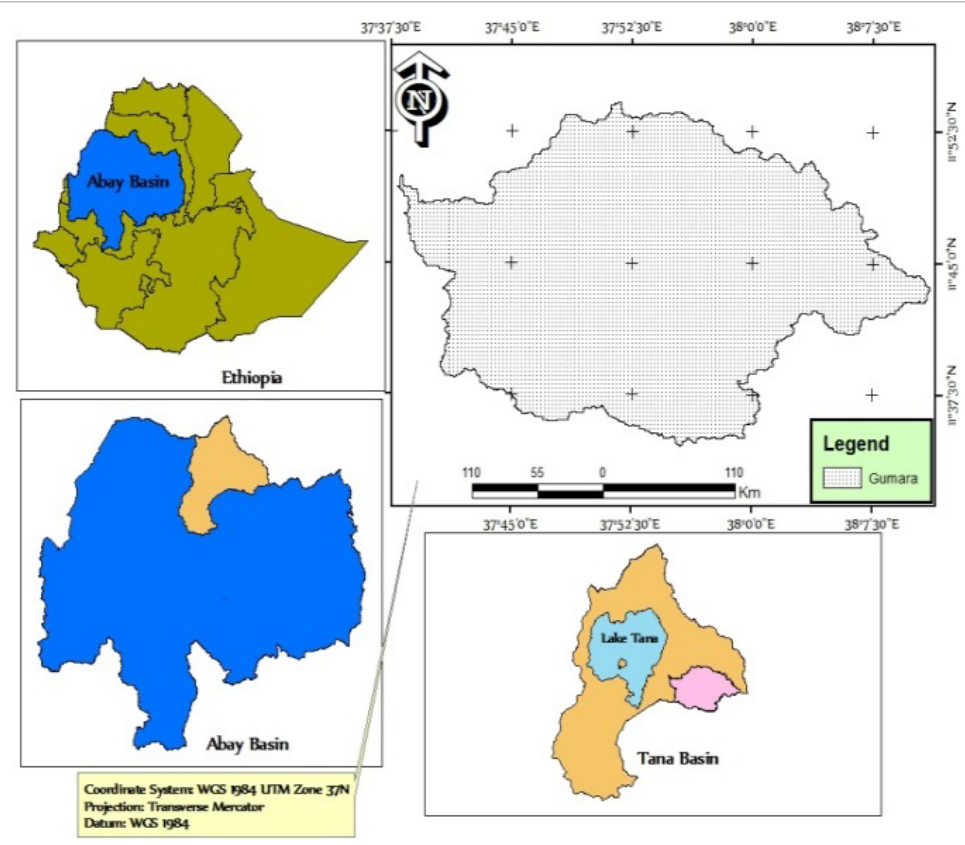

Figure 1: The map of geographical location of the study area.

versus observed flow of the catchment, SWAT CUP model was used for calibration and validation of model parameters selected by sensitivity analysis processes.

\section{SWAT model description}

The Soil and Water Assessment Tool (SWAT) is a versatile, physically semi - distributed model with spatial and temporal variability consideration, for simulating runoff and sediment transportation of small and large watersheds. The model is a physical based, semidistributed and operating on daily time step [4]. As a physical based model, SWAT create Hydrological Response Units (HRUs) to represent spatial heterogeneity based on the specified threshold percentage of the watershed land use, soil types and slope.

The model provides two methods of surface runoff calculation: one is the runoff curve number method developed by the Soil Conservation Service (SCS) of the United States Department of Agriculture (USDA, 1986) and the other is through the Green-Ampt infiltration method. Runoff is generated from given watersheds that are become saturated or during a storm period. Infiltration as initial abstraction measurement and plot studies in the Ethiopian highlands watersheds has shown that infiltration rate on hillsides with dominant sand and gravel cover can be higher than the greatest rainfall intensity with the same magnitude [5].

The hydrologic water balance and cycle simulated by SWAT model is based on the following water balance equation:

$\mathrm{SW}_{\mathrm{t}}=\mathrm{SW}_{\mathrm{o}}+\left(\mathrm{R}_{\text {day }}-\mathrm{Q}_{\text {surf }}-\mathrm{E}_{\mathrm{a}}-\mathrm{W}_{\text {seep }}-\mathrm{Q}_{\mathrm{gw}}\right)$

Where,

$\mathrm{SW}_{\mathrm{t}}$ is the final soil water content $(\mathrm{mm})$

$\mathrm{SW}_{\mathrm{o}}$ is the Initial Soil water content on daily bases $(\mathrm{mm})$

$t$ is the time in days

$\mathrm{R}$ is the amount of rainfall in daily bases $(\mathrm{mm})$

$\mathrm{Q}_{\mathrm{i}}$ is the surface runoff on day $(\mathrm{mm})$
$\mathrm{E}_{\mathrm{a}}$ is the amount of evapotranspiration in daily bases $(\mathrm{mm})$

$\mathrm{W}_{\text {seep }}$ is the amount the Vadose zone from soil profile on day ( $\mathrm{mm}$ )

$\mathrm{Q}_{\mathrm{gw}}$ is the amount of return flow on daily bases.

\section{Data collection and analysis}

Different data types that have been used to conduct this work were obtained from different sources, the study has required basically land use land cover, climate, and stream flow data of the study area to evaluate the relationship of land use change with the low stream flow of Gumara river. But to generate simulated flow and to evaluate the effect land use/cover change from the combined effects of climate and land use/ cover change on low stream flow of the catchment, SWAT model was used. The model uses various input data; these required data were: climate, land use/cover, Soil, DEM, and whether generator [6].

\section{Land use/land cover data}

The land use/cover images of the study area have been obtained from USGS earth explorer between path and row of 169 and 52 respectively. And this data has been processed by using ERDAS IMAGINE 2010. Two satellite images were taken in 1973 on 02 March and on the same day and month in 2013. The 1986 land use/cover data was also processed and taken for model calibration.

The three time period land sat satellite images were obtained from Landsat MSS, Landsat TM, and Landsat ETM+ respectively. The preprocessing and processing of theses land use/ cover data were done by using ERDAS IMAGINE 2010 and GIS 10.1 software.

Besides to this, the real field land use/cover data was collected by using GPS device to compare with the extracted 2013 land use/cover data by accuracy assessment tool of ERDAS IMAGINE 2010. Even if it was difficult to be sure, the historical land use/cover information was also collected by informal interviewing the elder people to compare the current and 1973 land use/cover data [7]. 


\begin{tabular}{|c|c|c|c|c|}
\hline Sensor & $\begin{array}{c}\text { Date of } \\
\text { acquisition }\end{array}$ & $\begin{array}{c}\text { Path and } \\
\text { row }\end{array}$ & $\begin{array}{c}\text { Spatial resolution } \\
(\mathbf{m})\end{array}$ & Source \\
\hline $\begin{array}{c}\text { Landsat } 1 \\
\text { MMS }\end{array}$ & $01-02-1973$ & $181 / 52$ & $57 * 57$ & USGS \\
\hline Landsat 5 TM & $28-03-1986$ & $169 / 52$ & $30 * 30$ & USGS \\
\hline Landsat 8 OLI & $06-01-2013$ & $169 / 52$ & $30 * 30$ & USGS \\
\hline
\end{tabular}

Table 1: Sensor, Acquisition dates, Path/Row, and Resolution of the study area image.

\section{Land use/ land cover classification}

Data pre-processing: The land use/cover images of the study area have been obtained from USGS earth explorer between path and row of 169 and 52 respectively. These images were free from cloud cover and they have been geometrically corrected and projected to the World Geodetic System (WGS-84 UTM Zone $37 \mathrm{~N}$ ). The Landsat images were also resampled using the nearest neighbor algorithm to keep the original brightness and pixels values. Table 1 shows the acquisition dates, sensor, path/row, resolution, and the providers of the images. The acquisition dates of the 1973, 1986 and 2013 images correspond to the dry season of the study area while the images have resolutions of 57 $\mathrm{m}$ for 1973 and $30 \mathrm{~m}$ for 1986 and for 2013.

This data has been processed by using ERDAS IMAGINE 2010. Among the three land use/cover data, the 1986 were used to calibrate SWAT model parameters, whereas the others 1973 and 2013 land use/ cover data were used for the study of change and its effect on low flow of the catchment [8].

The three time period land sat satellite images were obtained from Landsat MSS, Landsat TM, and Landsat OLI respectively. The Landsat multispectral scanner (MSS) bands 1, 2, 3, and 4 cover the spectral range between $0.45-1.10 \mu \mathrm{m}$. Both the Landsat thematic mapper (TM) and enhanced thematic mapper (ETM+) bands 1, 2, 3, 4, 5, and 7 cover the spectral range between $0.45-2.5 \mu \mathrm{m}$. Observations by bands 1-3 represent visible electromagnetic (EM) radiances at wavelengths 0.45 $0.52,0.52-0.60$, and $0.63-0.69 \mu \mathrm{m}$, respectively. Band 4 corresponds to the near infrared wavelengths at $0.76-0.90 \mu \mathrm{m}$ while bands 5 and 7 correspond to the mid-infrared wavelengths at 1.55-1.75 and 2.08-2.35 $\mu \mathrm{m}$, respectively. The land cover images were created using the band combination of 7, 4, 2 (Landsat TM and OLI) images of 1986 and 2013) and 4, 2, 1 (Landsat MSS image of 1973) to allow visual interpretation of the images in their true color. The preprocessing and processing of theses land use/ cover data were done by using ERDAS IMAGINE 2010 and GIS 10.1 software.

Besides to this, the real field land use/cover data was collected by using GPS device to compare with the extracted 2013 land use/cover data by using accuracy assessment tool of ERDAS IMAGINE 2010. Even if it was difficult to be sure, the historical land use/cover information was also collected by informal interviewing the elder people to compare the current and 1973 land use/cover data [9].

Climate data: The climate data were collected from National Metrological Agency of Ethiopia for five stations including, Bahir dar, Debretabore, Werota, Wanzaye and Amed ber. However, only three metrological stations (Bahir dar, Debretabore and Werota) were used; this was due to long period of record like more than 30 years' data is needed.

The missing data in both rain fall and temperature data were filled by long time daily average value. There were also some outliers in the raw data, identified by filtering and drawing the graph by the help of excel sheet and it was corrected by replacing long time average daily data. Then, the whole years of daily rain fall and temperature data were stacked and prepared with respect to the SWAT using format [10].

Model calibration and validation: The model has been calibrated by (1986-1991) climate and 1986 land use land cover data so as to determine the representative value of parameters on the study area through changing the values of selected parameters until the maximum efficiency of SWAT model was obtained. All objective functions compared the simulated and observed value of the model with different statistical formula.

For many numbers of iterations, the manual calibration is better than automatic one in a way that it takes in to account the consideration of the real physical characteristics of the catchment. Every parameter has their value ranges to be iterated; the model has iterated the calibration process 2000 times of simulation which is the maximum possible number of iteration that SWAT CUP model can do.

After the model, has been calibrated, the consistency of the model parameter values has also been verified by using four-year (1992-1995) climate data and 1986 land use/cover data [11].

SWAT model efficiency: In doing the calibration and validation, the performance of the model was assessed by using coefficient of determination, relative volume error and most importantly NashSutcliffe efficiency. The efficiency E proposed by Nash and Sutcliffe is defined as one minus the sum of the absolute squared differences between the predicted and observed values normalized by the variance of the observed values during the period under study. It is computed as:

The range of NS lies between 1 and $-\infty ; 1$ indicates that the best fit of the model or the model generates similar values of flow with the measured values. To accept the model, the NS values should be more than 0.5 .

$$
N S=1-\frac{\sum_{i=1}^{n}\left(Q_{\operatorname{sim}(i)}-Q_{o b s(i)}\right)^{2}}{\sum_{i=1}^{n}\left(Q_{o b s(i)}-Q_{o b s}\right)^{2}}
$$

$\mathrm{RV}_{\mathrm{E}}$ determines the ratios of differences of total simulated and total observed value of flow; it doesn't show us the difference of values with in that corresponding time of measured and simulated discharge values. In other words, even if the value of $\mathrm{RV}_{\mathrm{E}}$ of the model is small enough, it is not necessarily mean that the model has good efficiency [12].

$$
R V_{E}=\left(\frac{\sum_{i=1}^{n} Q_{\text {sim }(i)}-\sum_{i=1}^{n} Q_{o b s(i)}}{\sum_{i=1}^{n} Q_{o b s(i)}}\right) 100 \%
$$

SWAT model structure: To simulate stream flow, SWAT model was constructed starting from watershed delineation. Digital elevation model (DEM) with $30^{\star} 30 \mathrm{~m}$ resolution is the basic and primary ground for watershed delineation and it was used as an input to compute the slope of the catchment. After the watershed, had been delineated, other hydrological response units like, slope, soil and land use characteristics of the model were masked and overlaid with respect to delineated watershed. The model was classified the catchment in to 24 HRUs or sub basins [13].

On the other side, climate data was used as another input in SWAT model for simulation of flow. Daily maximum and minimum temperature, daily rainfall and whether generator was used as in climatic input for the model, the others like solar radiation, relative 
humidity and wind speed data which are designed to compute the evapotranspiration of the catchment by the model itself were generated on the whether generator data obtained from IWMI.

Then after the process of defining HRUs and importing whether station data, set up of SWAT model was arranged and it had simulated stream flow by default parameters. To fit the simulated flow with observed flow of the catchment, important parameters were selected by the processes of sensitivity analysis and by those parameters the model was calibrated by using automatic calibration (SWAT CUP 2012) until the maximum value of model efficiency was obtained [14,15].

Impact of land use/cover change on low stream flow: Once the model was calibrated by 11 most important parameters and validated the values of these parameters, SWAT model has simulated stream flow two times to evaluate the impacts of land use/cover change on stream flow. The values of those 11 parameters were constant for all simulation processes. First stream flow was simulated by using 1973 land use land cover data and 1973-1982 climate data which was considered as the base line for change study. Secondly, the flow was simulated by 2013 land use land cover data and 1973-1982 climate data [16].

The effects of land use land cover and combined changes were evaluated in such a way that the difference between:

Simulation one and simulation two=effect of land use land cover change.

After the flow has been simulated, the effect of land use/cover change on the normal stream flow of the catchment was determined. The low flow of the base line and change study periods were selected with in the simulated flow generated by using 7 day sustained method.

\section{Results and Discussion}

\section{Land use/cover classification accuracy assessment}

This assessment is carried out to evaluate the classification efficiency of the ERDAS IMAGINE2010 software so as to represent the current land use /cover map of the study area. The process had determined how effectively pixels were grouped in to the correct feature classes under investigation. It is accomplished the classified image with the ground by the help of field survey or reference map.

To assess the efficiency of classification accuracy, confusion matrix was developed. To conduct this assessment 120 random points were decided to be collected using thump rule; states that 30 points for each land use land cover class and the image was containing four classes.

\begin{tabular}{|c|c|c|c|c|c|c|}
\hline \multicolumn{7}{|c|}{ Reference } \\
\hline \multirow{6}{*}{ 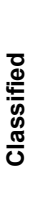 } & Class & Grass land & Forest & Cultivation & Bush land & Total \\
\hline & Grass land & 7 & 0 & 3 & 0 & 10 \\
\hline & Forest & 0 & 5 & 0 & 1 & 6 \\
\hline & Cultivation & 6 & 0 & 81 & 3 & 90 \\
\hline & Bush land & 0 & 1 & 0 & 13 & 14 \\
\hline & Total & 13 & 6 & 84 & 17 & 120 \\
\hline
\end{tabular}

Table 2: LULC confusion matrix.

\begin{tabular}{|c|c|c|c|c|}
\hline Class & $\begin{array}{c}\text { Producer's } \\
\text { accuracy (\%) }\end{array}$ & $\begin{array}{c}\text { Omission } \\
\text { error (\%) }\end{array}$ & $\begin{array}{c}\text { User's } \\
\text { accuracy (\%) }\end{array}$ & $\begin{array}{c}\text { Commission } \\
\text { error (\%) }\end{array}$ \\
\hline Grass land & $7 / 13=53.85 \%$ & 46.15 & $7 / 10=70.00 \%$ & 30 \\
\hline Forest & $5 / 6=83.33 \%$ & 16.66 & $5 / 6=83.33 \%$ & 16.66 \\
\hline Cultivation & $81 / 84=96.43 \%$ & 3.57 & $81 / 90=88.89 \%$ & 11.11 \\
\hline Bush land & $13 / 17=76.47 \%$ & 23.53 & $13 / 14=92.86 \%$ & 7.34 \\
\hline
\end{tabular}

Table 3: The LULC classification accuracy assessment.

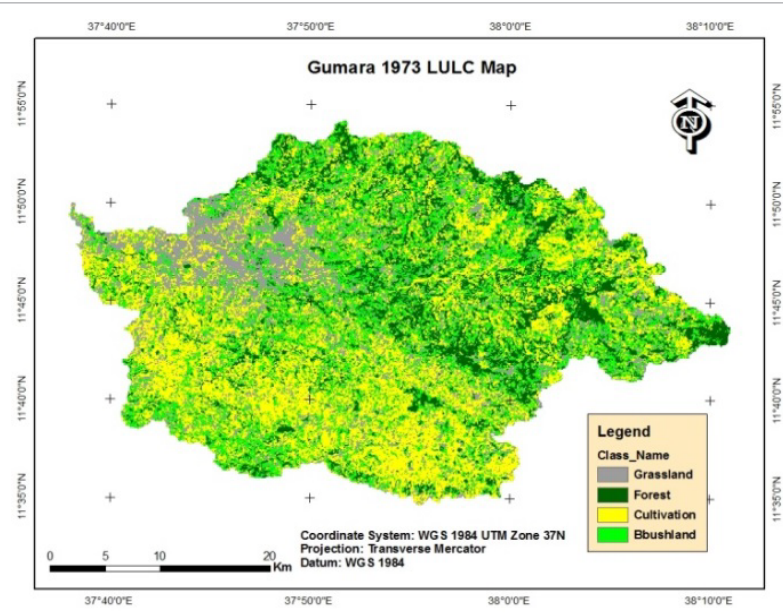

Figure 2: 1973 LULC map of Gumara watershed.

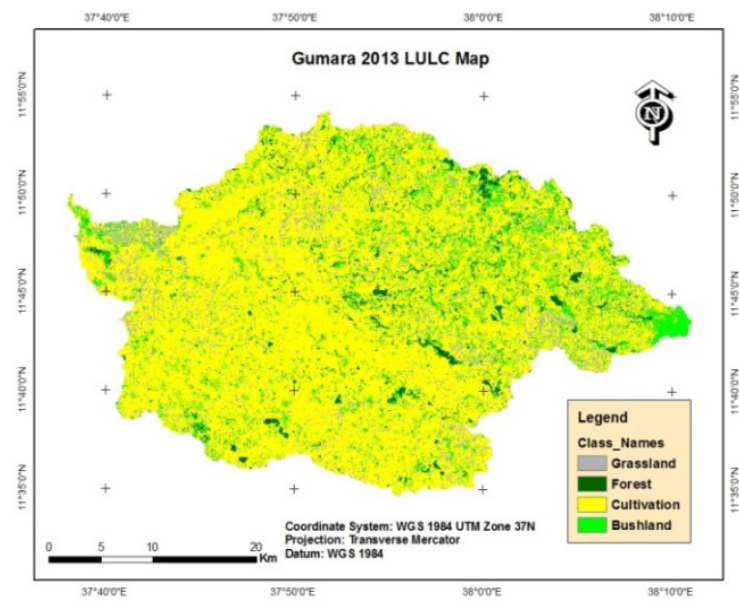

Figure 3: 2013 LULC map of Gumara watershed.

Random points were generated using random point generation tool of Arc GIS software [17].

The numbers of points for each class were determined by their proportional area coverage of the total area of the map. These random points were compared to the real ground land use land cover classes through field survey in areas where it was accessible and reference map like quick bird and Google earth for the areas which were not accessible like mountain area, gorges, and very distant areas of the catchment. On the Table 2, the bold text cells are the numbers of points in each land use land cover classes correctly found on the same classes of the ground. The two totals or the last row and column of Table 2 comprises the numbers of points in each classes of the classified map and the numbers of points of each class on the ground respectively which is proportional out of the total (120) control points.

\section{Land use/Cover classification result}

Each land use land cover map has been classified in to four classifications which are forest, bush land, cultivation and grass land (Table 3). The land use land cover map of 1973 is considered as the base line or zero change of the study. The land use land cover classification of 1973 is shown on the map (Figure 2).

The study has tried to show the current land use land cover situation 
of the study area, 2013 land use land cover map had been prepared to show the extent of change by comparing with the base map (1973). It showed the significant conversion of one land use land cover to the other; agriculture has been expanding and highly dominating other classes. It is because of the increment of population and consequently the society had gone to destruct and expand the area of cultivation land to maintain the need of food security [18].

This land use land cover map was also used for accuracy assessment of the whole land use land cover classification of the catchment. It had been compared with the actual land use land cover nature. The current land use/land cover classes of the study area are shown by the following map (Figure 3).

The accuracy assessment of these land use land cover classification has been done and the result was evaluated based on the values of Kappa statics and the overall accuracy by developing confusion (error) matrix of four classes. It was having $73.33 \%$ and $88.33 \%$ of Kappa statistic and overall classification accuracy respectively.

\section{Land use / cover change pattern and rate}

The pattern and rate of land use/cover change of the study area, has been shown by comparing 1973 and 2013 land use/cover of the study area. The former (1973) land use/cover classification was considered as the base map. Based on that, the extent, and the rate of how much parts of each land use/cover classes has been changed to the other classes had been computed by comparing with 2013 land use/cover map. The extent and rate of land use / cover change between 1973 and 2013 is shown on the Table 4.

\section{Land use/cover change effect on the low flow of the catchment}

The annual low flow values were selected from the two decadal periods from already generated flow by land use land cover change of the catchment. Seven day sustained low flow model was used to extract representative low flows for each year in decadal time period [19].

\begin{tabular}{|c|c|c|c|c|}
\hline LULC classes & 1973 Area (ha) & 2013 Area (ha) & Change (ha) & $\mathbf{( \% )}$ \\
\hline Grassland & 19464.9 & 11110.4 & 8354.5 & 75.19 \\
\hline Forest & 22924.5 & 4638.13 & 18286.37 & 394.3 \\
\hline Cultivation & 47936.5 & 96092.9 & 48156.4 & 100.5 \\
\hline Bush land & 36860.2 & 15344.6 & 21515.6 & 140.2 \\
\hline Total & 127186.1 & 127186.03 & & \\
\hline
\end{tabular}

Table 4: Land Use /Cover Change Pattern and Rate.

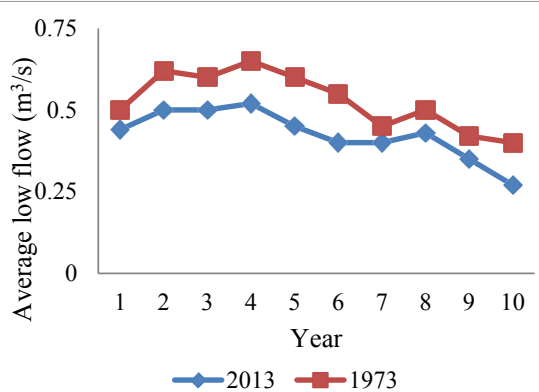

Figure 4: LULC change effect on low flow showing curves.

\begin{tabular}{|l|l|l|l|l|l|l|l|l|l|l|l|} 
Year & $\mathbf{1}$ & $\mathbf{2}$ & $\mathbf{3}$ & $\mathbf{4}$ & $\mathbf{5}$ & $\mathbf{6}$ & $\mathbf{7}$ & $\mathbf{8}$ & $\mathbf{9}$ & $\mathbf{1 0}$ & Average \\
\hline
\end{tabular}

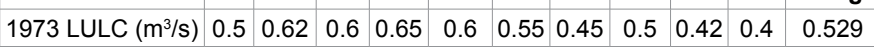

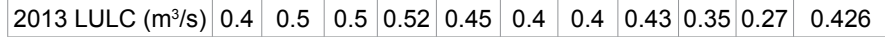

Table 5: The effect of LULC change on the flow of Gumara watershed.
The result had shown that most of the area of the catchment has been covered by cultivation land because of agricultural expansion and consequently the other land use/cover classes had severely been depleted. Especially the forest and bush land classes which are very important physical catchment characteristics to reducing the overland flow and soil erosion of the catchment have been degraded. Due to decreasing of infiltration process, ground water recharge is significantly reduced and consequently stream flow during dry seasons which is generated from ground water has been severely affected. Currently these two-land use/cover classes have covered very small areas i.e. $3.65 \%$ and $12.06 \%$ respectively of the total area of the catchment. Due to this, the low flow trend of the catchment is decreasing (Figure 4).

The overall gap of these two curves showed the decreasing trend of low flow because of land use land cover change of the catchment. The result indicates that the degradation of vegetation or expansion of agricultural land has been considerably affecting the environmental flow of the catchment. The decreasing of environmental flow has also been affecting the socio-economic situation of the study area. In terms of magnitude, the result has also been evaluated to quantify that exactly how much the land use land cover change has been affecting the low flow trend of the catchment [20].

The mean annual minimum flow for both decades are showed by the last column of the Table 5 ; which accounts $0.53 \mathrm{~m}^{3} / \mathrm{s}$ by the base map and $0.43 \mathrm{~m}^{3} / \mathrm{s}$ by 2013 land use land cover. The mean value difference is $0.1 \mathrm{~m}^{3} / \mathrm{s}$; the trend is decreased by $18.87 \%$. Besides to the mean value difference, the minimum of low flow values within ten values of each decade have also been used for evaluation of the change of effect study. The values obtained by the base map and 2013 land use land cover map are $0.4 \mathrm{~m}^{3} / \mathrm{s}$ and $0.27 \mathrm{~m}^{3} / \mathrm{s}$ respectively; the difference is $0.13 \mathrm{~m}^{3} / \mathrm{s}$ which is reduced by $32.5 \%$

The reason is stated by Kuchment [21] the higher infiltration capacity of forest soils increases the opportunity for groundwater recharge, and the flow of rivers tends to be more sustained; which indicates that in Gumara watershed on 1970s there was more or less better vegetation coverage than the current time and therefore the base flow or environmental flow of the catchment has been decreasing.

\section{Conclusions}

Landsat images were collected on USGS earth explorer and processed by ERDAS IMAGINE 2010 and ArcGIS 10.1 software. The change of land use land cover of the catchment has been evaluated by comparing the 1973 and 2013 year of land use land cover data. The land use/cover analysis has indicated that most of the previous land use/cover types like forest and bush land have been changed in to agriculture lands. This is due to the expansion of population and competition for the natural resources. This distractive change of land use cover has been significantly affecting the dry season flow or base flow of the catchment.

\section{References}

1. Miller S (2002) Integrating Landscape Assessment and Hydrological Modeling for Land Cover Change Analysis. Journal of American Water Ressource Association 38 : 915-929.

2. Luijten JC, Jones JW, Knapp EB (2000) Dynamic modeling of strategic water availability in the Cabuyal River, Columbia : the impact of Land Cover change on the Hydrological Balance. Advances in Environmental Monitoring and Modelling 1: 36-60.

3. Turner BL, Skole D, Snderson S, Fischer G, Fresco L et al. (1995) Land Use and Land Cover Change Science/Research Plan. HDP Reprt Series No 7.

4. Neitsch S, Arnold J, Kiniry J, Williams J (2005) Soil and Water Assessment Tool 
Citation: Chakilu GG, Moges MA (2017) Assessing the Land Use/Cover Dynamics and its Impact on the Low Flow of Gumara Watershed, Upper Blue Nile Basin, Ethiopia. Hydrol Current Res 7: 268. doi: 10.4172/2157-7587.1000268

Page 6 of 6

Theoretical Documentation-Version 2005. Grassland, Soil \& Water Research Laboratory, Agricultural Research Service, and Blackland Agricultural Research Station, Temple, Texas.

5. Ma X, Xu J, Luo Y, Aggarwal SP, Li J (2009) Responses of hydrological processes to land-cover and climate changes in Kejie watershed, south-west China. Hydrological Processes 23: 1179-1191.

6. Yeshaneh E, Wagner W, Exner-Kittridge M, Legesse D, Blöschl G (2013) Identifying Land Use/Cover Dynamics In the Koga Catchment Ethiopia from Multi-scale Data, and Implications for Environmental Change. ISPRS International Journal of Geo-Information 2: 302-323.

7. FAO-Food and Agriculture Organization of the United Nations: Global Forest Resources Assessment Main report, FAO Forestry Paper 163, Food and Agriculture Organization of the United Nations, Rome, 2010.

8. Dwivedi R, Sreenivas K, Ramana K (2005) Land Use Land Cover Change Analysis in Part of Ethiopia Using Landsat Thematic Mapper Data. International Journal of Remote Sensing 26: 1285-1287.

9. Chong Xu (2005) Hydrology Text Book of Hydrological Models. Uppsala University Department of Earth Sciences Hydrology Earth Sciences Centre.

10. DeFries R, Eshleman KN (2004) Land-use change and hydrologic processes: a major focus for the future. Hydrol Process $18: 2183-2186$.

11. Mati BM, Mutie S, Gadain H, Hame P, Mtalo F (2008) Impacts of land-use/ cover changes on the hydrology of the trans boundary Mara River, Kenya/ Tanzania, Lakes Reserv. Res Manage 13: 169-177.

12. Brandon R, Bottomley BA (1998) Mapping Rural Land Use \& Land Cover Change In Carroll County, Arkansas Utilizing Multi-Temporal Landsat Thematic
Mapper Satellite Imagery: 1984-1999, University of Arkansas.

13. Moriasi DN, Arnold JG, Van Liew MW, Bingner RL, Harmel RD et al. (2007) Model Evaluation Guidelines for Systematic Quantification of Accuracy in Watershed Simulations. Transactions of the ASABE 50: 885-900.

14. Nash JE, Sutcliffe JV (1970) River flow forecasting through conceptual models Part I - A discussion of principles. J Hydrol $10: 282-290$.

15. Legesse D, Vallet-colomb C, Gasse F (2003) Hydrological response of a catchment and land use change in tropical Africa: Case study south central Ethiopia. Journal of hydrology 275: 67-85.

16. Hu Q, Willson GD, Chen X, Akyuz A (2005) Effects of climate and land cover change on stream discharge in the Ozark Highlands, USA. Environmental Modeling \& Assessment 10: 9-19.

17. Sherbinin D (2002) Land-Use and Land-Cover Change, A CIESIN Thematic Guide. Retrieved 6 15, 2013, International Earth Science Information Network (CIESIN) of Columbia University

18. Smakhtin VU (2001) Low flow hydrology: a review. J Hydrol 240: 147-186.

19. Homdee T, Pongput K, Kanae S (2011) Impacts of land cover changes on hydrologic responses: a case study of chi river basin, Thailand. Journal of Japan Society of Civil Engineers, Ser. B1 (Hydraulic Engineering) 67: I_31-I_36.

20. Zhang YK, Schilling KE (2006) Increasing stream flow and base flow in Mississippi River since the 1940s: Effect of land use change. Journal of Hydrology 324 : 1-4.

21. Kuchment LS (2008) Runoff generation (genesis, models, prediction). Water Problems Institute of RAN, p: 394. 